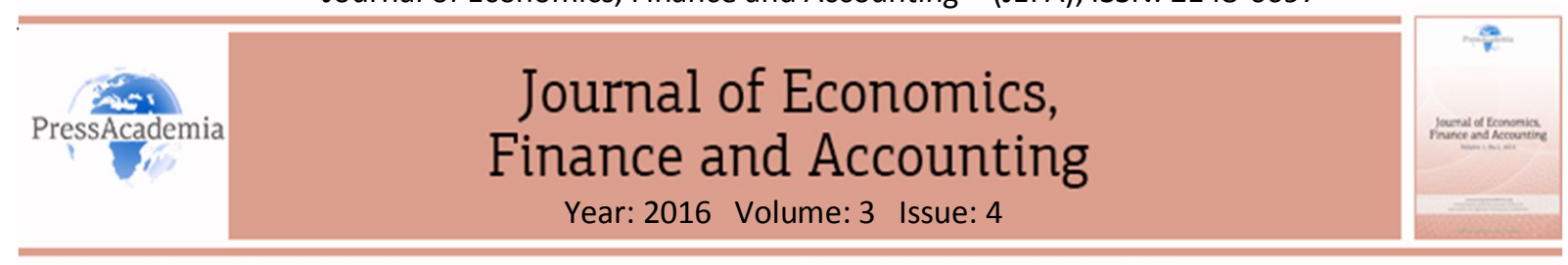

\title{
EFFECTS OF DEPRECIATION METHODS ON PERFORMANCE MEASUREMENT METHODS: A CASE OF ENERGY SECTOR
}

\section{DOI: 10.17261/Pressacademia.2016.347}

\author{
Huseyin Mert ${ }^{1}$, Sema Erkiran Dil ${ }^{2}$ \\ ${ }^{1}$ Okan University. huseyin.mert@okan.edu.tr \\ ${ }^{2}$ Okan University. semaerkirann@gmail.com
}

\begin{abstract}
The companies amortize according to the tax laws and accounting standards for their assets recorded in their actives. The amounts calculated according to the useful life based on the standards and tax regulations and depreciation rates connected with it a re ascertained and recognized as an expense pursuant to periodicity concept. Since the amounts recognized as an expense directly affects the profit and loss, it is important for the companies to calculate the useful life of their fixed assets and to determine and implement the proper method. Besides, current performance measurement methods confront us with different approaches and the methods being used enhances the success, value of the companies while being a guide. In this research, the effects on performance measurement methods of current depreciation procedures according to accounting standards has been analyzed and the issue has been tried to assessed by taking the energy industry into consideration. Within this scope, the performances in 2014-2015 of energy companies active in Istanbul Stock Exchange are examined based on Economical Added Value (EVA) and Cash Flow Return on Investment (CFROI) models and it was determined whether or not the companies has created value.
\end{abstract}

Keywords: Depreciation, TMS Depreciation, performance measurement methods JEL Classification: M41, M42

\section{INTRODUCTION}

Financial statements are reports showing the financial status and operational results of business entities. Entities should compare the previously set targets with the actual results achieved and make and implement the required decisions depending on the adequacy of meeting the expected growth and development. Performance evaluation system becomes important at this point. The reason is, performance management aims at setting goals, monitoring achievements and evaluating the results.

It would be healthier and more realistic for the conduct of operational activities to make decisions in line with the financial statement items, so financial analysis should be made at regular intervals. Selected accounting policies and the analysis made would reflect the entity's operational performance and also would show its success on the financial statements.

Furthermore, entities act in accordance with the previously determined accounting policies. Adopting different accounting policies causes difference in reporting the exactly same events/facts. For this reason, the figures on the financial statements are the results of these accounting policies. Selection of accounting policies affects the decisions of entity's entire stakeholders. Accounting policy would be determined in this regard through knowledge and understanding and the effect on the profit and loss of depreciation methods, which would have significant effect on the entity's financial statements, to determine the correct method for the industry in which the entity operates. 
The present paper discusses the means by which entities could systematically benefit from the depreciation methods selected pursuant to Turkish Accounting Standards and the principle of periodicity, in consideration of costs and useful physical lives of their assets as well as their own accounting policies based on these assets, and how these methods would affect the relevant entities' financial statements. The paper presents the picture regarding current performance measures, namely Economic Value Added (EVA), Cash Flow Return on Investment (CFROI), Cash Value Added (CVA), Market Value Added (MVA) as financial and non-financial measures with respect to which the entities can gather and present information about their internal value addition processes. Furthermore, the analysis covered the independent audit reports for year 2014-2015, of the energy sector firms; Ak Enerji, Aksa Enerji, Aksu Enerji, Ayen Enerji, Orge Enerji, Zorlu Enerji, which are all registered with the Public Disclosure Platform (KAP), as the data pertaining to these firms are representative in terms of general practices in light of the Cash Flow Return on Investment model, which had been of significant value in terms of developing an application to serve as model to explain the Economic Value Added model. The data taken from said financial statements are arranged in separate tables for years 2014 and 2015 to calculate the firms' economic depreciation, economic lives of their depreciation, gross cash flows, gross cash investments, weighted average cost of capital and cash flow returns on investments. There after; efforts were made to show via these tables, how the calculations are performed, which items are included among data points and the differences to arise in terms of the results/rates/ratios achieved even though all the firms are from the same sector.

\section{DEPRECIATION ACCORDING TO TURKISH ACCOUNTING STANDARTS}

Comprehensive provisions regarding depreciation are set forth in TMS 16 "Tangible Fixed Assets" Turkish Accounting Standard (TMS). This Standard is promulgated in Turkish Official Journal No.26040 to be applicable to accounting periods starting after 31.12.2005.

According to TMS 16 Tangible Fixed Assets Standard, "depreciation" means systematic distribution of the depreciable amount of an asset during the asset's useful life. Again according to the same Standard, "depreciable amount" means the amount found by deducting the residual value from an asset's cost or other amounts considered as cost.

Depreciable Amount and Depreciation Period; An asset's depreciable amount is systematically distributed over the asset's useful life. Distribution of fixed assets' costs to their useful lives is due to periodicity principle. When determining the asset's book value on time basis, the period during which the asset is practically used by the entity shall be considered and not the asset's physical service life. To determine the useful life of an asset, factors such as technological obsolescence, wear \& tear etc. should be considered. The entity's maintenance \& repair policies also affect this determination. Same assets can have shorter or longer economic lives in line with the maintenance \& repair policies of different owners. Similarly, same asset can have shorter or longer economic lives according to the intention of use.

Residual value or the useful life should be revised at least at the end of each accounting period; in case the prospects differ from the previously made forecasts, changes should be recorded as "changes in accounting forecasts" in accordance with TMS 8 "Accounting Policies, Changes and Mistakes in Accounting Forecasts" Standard. Depreciation shall be reflected on financial statements as long as the asset's residual value does not exceed its book value, even if its real/actual value exceeds the book value. Maintenance and/or repair of an asset does not eliminate the requirement for depreciation. Depreciable amount of an asset is found by deducting the residual value. In practice, an asset's residual value is generally minor and therefore insignificant for calculation of the depreciable amount. An asset's residual value can be increased to an amount equal to or greater than its book value. In such case, the asset's depreciation expense shall be equal to zero until the residual value decreases to an amount less than its book value. An asset shall start to be depreciated when the asset is or becomes usable, for instance when the asset is brought to a state and location desired by the entity management. An asset's depreciation shall be ceased at the earlier date among the dates when the asset is classified as an asset held for sales purpose (or included in a group classified as assets held for sales purpose) as per TFRS 5 or when the asset is derecognized in the entity's relevant financial statement (balance sheet). For this reason, depreciation of an asset shall not be ceased when the asset becomes idle or put out of service unless the asset is fully depreciated. However, depreciation expense can be zero during periods of no 
production if the units of production depreciation method is used. Future economic benefits of an asset are in fact utilized by the entity during the asset's usage period. However, technical or commercial impairment and wear \& tear when the asset is at idle state usually cause decreases in the potential economic benefits to be derived from such asset.

All of the following factors are considered in determining an asset's useful life.

(a) Expected use. Use is evaluated according to the expected capacity or physical production of the asset.

(b) Expected physical wear \& tear. Expected physical wear \& tear depends on operational factors such as the number of shifts during which the asset is used, regular maintenance \& repair schedule and maintenance \& repair operations the asset gets subject to during idle times.

(c) Technical or commercial impairment due to production changes or developments, or changes in the market demand for the product or service produced by the asset. Future decreases expected in the sales price of an item produced through use of an asset can create expectancies for technical or commercial impairment of the asset's value, therefore can reflect a decrease in the future economic benefits expected from the asset.

(d) Legal or similar restrictions on the asset's use such as the dates when the relevant leasing procedures shall become invalid.

Useful life of an asset is determined according to the benefit expected from that asset by the entity. The entity's asset management policy can require disposal/sale of assets after a certain period of time or after utilization of the assets' future economic benefits at certain rates. Therefore, an asset's useful life can be shorter than its economic service life. Forecasting an asset's useful life is a matter of judgment based on the entity's experience about similar assets. Land and buildings are separable fixed assets even when they are purchased in combination and are separately recognized and recorded. Lands have unlimited useful life except some types such as quarries and areas used for landfilling, therefore these lands are not depreciated. Buildings have limited useful lives, therefore these are depreciated assets. Rise in value of land on which a building is constructed shall not affect the depreciable amount of that building. In case the land cost includes the costs of dismantling, removal and restoration of the area, the portion of the land cost comprising of the foregoing costs shall be depreciated for the time where the entity benefits from bearing such costs. In some cases where the land itself may have limited useful life, depreciation is applied as to reflect the benefits to be derived from the use of such land.

Depreciation Methods: Depreciation method used reflects the utilization model expected to be applied by the entity regarding the asset's future economic benefits. Depreciation method applied to an asset should be revised at least at the end of each accounting period. In cases where a significant change occurs in the utilization model of the asset's future economic benefits, the method should be changed to reflect the changed model. Such a change shall be recorded as a change in accounting forecasts in accordance with TMS 8 Standard.

The entities select the method which best reflects the utilization model of the asset's future economic benefits. The selected method shall be consistently applied to each period unless a change occurs in the utilization model of the asset's future economic benefits. A depreciation method based on the revenue obtained from an activity involving use of an asset is not accepted. Revenue obtained from an activity involving use of an asset usually reflects factors other than the utilization of the asset's economic benefits. For instance, the revenue is affected by other inputs and operations, sales activities, sales volumes and prices etc. The price component of revenue can be affected by the inflation rate which has nothing to do with the asset's utilization means.

Various depreciation methods can be used to systematically distribute the depreciable amount of an asset throughout its useful life. These are:

- Straight Line Method,

- Declining Balance Method,

- Units of Production Method. 
Standards deal with the impact of the selection and implementation of the selected depreciation model on the period end results and therefore on the comparison of the entity's financial statements based on years. In other words, standards stipulate a consistent use of depreciation methods throughout the periods. Unless a good justification exists for changing a selected depreciation method, the selected method is expected to be used consistently during the consecutive periods. Impact of the change shall be measured within the accounting period where such change occurs and the change itself should be explained together with the reason justifying the change.

Straight Line Method: This method is commonly used since it is quite simple as it replaces the time function with the utilization function in the depreciation formula. Also called the regular depreciation method, this method is based on the principle of applying the fixed percentage found according to the asset's service life to the value which remains after deducting the salvage value from the fixed asset's cost. In Straight Line method, the asset's depreciation expense is fixed during its useful life as long as the residual value remains the same. Straight Line Depreciation formula is as follows:

Annual Depreciation Amount = (Cost of Fixed Asset - Residual Value) $/$ Estimated Useful Life

Declining Balance Method: In this method, depreciation expense decreases during the asset's useful life. It is based on the calculation of an asset's depreciable value with the help of decreasing fractions throughout its economic life. Thus, the depreciation amount decreases each year. The sum of the fractions used shall be equal to 1 (one) at the end of depreciation period, which means that the entire value of the depreciable asset is allocated to the depreciation amounts during its economic life.

Annual Depreciation Amount $=$ Book Value at Period Start x (Regular Depreciation Rate $\times 2$ )

Units of Production Method: In this method, depreciation is determined according to the expected use or production amount.

Depreciation Rate $=($ Cost of Fixed Asset - Residual Value) / Estimated Total Production (during its entire useful life)

Annual Depreciation Amount $=$ Depreciation Rate $x$ Annual Production Amount

Annual Depreciation Amount $=$ Depreciation Ratio $\times$ Annual Production Amount

\section{PERFORMANCE MEASUREMENT METHODS}

Performance measures provide information to investors and managers about the value addition processes within the entity. Internally, entity managers should rely on performance measures to monitor the value addition processes within the entity and to obtain information required for appraisal of current performance. Externally, performance measures can be used for making comparisons between firms and as an indicator for the entity's future performance. Design of the performance measurement system should be compliant with the entity's strategic goals. Moreover, selection of performance measures to be used for restriction of managers' behaviors is an important issue.

General review of the existing literature about performance measures shows the existence of numerous instruments written on Economic Value Added (EVA) and Market Value Added (MVA), however the number of instruments written on CFROI and CVA is quite few. Günther (1997) compared CFROI, CVA and EVA methods in the article prepared about the firms listed on German Stock Exchange and found CVA to be relatively better compared to the other ones. Clinton and Chen (1998) examined the relation between the stock yields of 325 firms and their CVA, CFROI and EVA values during the sampling period 1991-1995. At the end of this research, the authors did not find any correlation between the EVA and CFROI values and stock yields. Fernandez (2002) examined the increase in CVA and income of shareholders and found 1.7\% correlation, thus suggested that CVA is not a very meaningful measure for measuring a firm's performance. Li and Guo (2003) compared CVA and EVA methods in their research and found that CVA method is more convenient in determining shareholder value due to certain deficiencies seen in EVA method. Urbanczyk, Jaroszewicz and Urbaniak (2005) examined the feasibility of EVA and CVA for Poland as value based performance measurement methods and concluded that the two methods are feasible. Jacops (2007) compared EVA, CVA and NVA as performance measurement 
methods and argued that NVA is a better measurement method compared to the other two methods. Hejazi and Oskouei (2007) examined the relation between the stock yields and CVA \& Price/Earnings ratio for the period 1999-2003 for 85 industrial firms listed in Tehran Stock Exchange. The result of this research showed that CVA is a better measure than Price/Earnings ratio for explaining stock yields. Erasmus (2008a) examined the relation between adjusted market yield and Residual Income, Cash Flow, EVA, CFROI and CVA for the period 1991-2005. According to the results of this research, he determined that value based measures cannot produce results as good as the results obtained from conventional accounting measures. Bayrakdaroğlu and Ege (2009) calculated CFROI figures of 19 entities listed in Istanbul Stock Exchange and subject to national industrial sub-index and determined that industrial companies show slightly better performance. Ünlü Ulaş (2014) Cash Flow Return on Investment (CFROI) and Cash Value Added (CVA) Methods: The author made an empirical implementation on cement companies listed in Istanbul Stock Exchange. He found that only two companies could create value added for their stockholders and others could not and the reason for this was insufficient gross cash flow amounts and use of capital at high costs by companies, additionally the companies could not gain earnings more than the cost of the capital they use except for one company, the industry's operational cash flow amounts were not at sufficient levels and the company managers should create strategies and methods which would create shareholders value to overcome this issue.

Performance measures are examined in two categories:

- Financial measures, - Non-financial measures

Table 1: Financial Measures in Performance Appraisal (Measurement) ${ }^{1}$

\begin{tabular}{|l|l|}
\hline Conventional Measures & New Measures \\
\hline Earnings per Share & Economic Value Added \\
\hline Market Value & Market Value Added \\
\hline Sales Revenue & Cash Flow Return on Investment (CFROI) \\
\hline Return on Assets & Cash Value Added (CVA) \\
\hline Shareholder Total Earnings & Net Value Added (NVA) \\
\hline Cash Flow & Balanced Scorecard \\
\hline
\end{tabular}

\subsection{Economic Value Added (EVA)}

EVA is the measure of the value created upon comparison of the cost required to support the operations and the operational revenue. In other words, EVA measures the difference between the return on the entity's capital and the cost of this capital. A positive EVA value shows that value is created for the shareholders and a negative EVA value shows the contrary. EVA is the integral measure of financial performance according to Otley (1999). EVA is a specific performance measure and it is also the base of a broader performance measurement structure. According to Stewhart, EVA is the most directly related performance measure with creation of stakeholder value.

Economic Value Added $=$ Net Operating Profit After Tax - Cost of Invested Capital

It is possible to calculate EVA with a more clear expression in more detail.

\footnotetext{
${ }^{1}$ Bayrakdaroğlu, A., Ege I.., (2009) Performance Analysis of Entities Listed in Istanbul Stock Exchange with Cash Flow Return on Investment (CFROI) Method, Muhan Soysal Business Conference, METU, February 10
} 
Net Sales

- Operating Expenses

= Operating Profit (EBIT)

- Taxes

$=$ Net Operating Profit After Tax

- Cost of Capital (Capital Invested x Weighted Average Cost of Capital)

$=$ Economic Value Added

For calculation of Economic Value Added; operating profit is found by deducting the operating expenses made by entities during the period for the sales made from the net sales figure obtained at period end; taxes to be paid is deducted from this operating profit figure to determine the net operating profit after tax; economic value added amount is found by deducting cost of capital (paid capital and weighted average cost of capital component) from net operating profit after tax amount.

\subsection{Cash Flow Return on Investment (CFROI)}

CFROI is the method for measuring the expected return of an investment by considering cash flows and time value of money. In CFROI method, the figure found is compared with the cost of capital to decide whether an entity's investments are good, neutral or poor. For this reason, an entity should increase the difference between its CFROI and cost of capital to increase its business value.

CFROI of an entity is calculated by using four inputs.

1- The first input is the inflation adjusted annual gross investment amount.

Adjusted Gross Investment Amount $=$ Written Down Value + Accumulated Depreciation of Fixed Assets

2- Second input is the inflation adjusted annual gross cash flow amounts.

Adjusted Gross Cash Flows $=$ EBIT + Current Year Depreciation

3- Third input is the economic lives of assets.

4- And fourth input is the terminal value of non-depreciable assets (if any) at the end of their economic lives (e.g. land and buildings).

Table 2: Calculation of CFROI Components via Financial Statements ${ }^{2}$

\begin{tabular}{|c|c|c|c|}
\hline 1 & $\begin{aligned} & \text { Net Tangible Fixed Assets } \\
+ & \text { Accumulated Depreciation } \\
= & \text { Depreciable Gross Tangible Fixed Assets } \\
\div & \text { Depreciation Expense (annual) } \\
= & \text { Economic Lives of Assets (in years) }\end{aligned}$ & 2 & $\begin{aligned} & \text { Net Profit } \\
+ & \text { Depreciation Expense } \\
+ & \text { Interest Expense } \\
= & \text { Gross Cash Flows }\end{aligned}$ \\
\hline 3 & $\begin{array}{l}\text { Depreciable Assets } \\
+ \text { Intangible Assets } \\
\text { + Cash and Cash Equivalents } \\
\text { + Commercial and Related Receivables } \\
\text { + Other Current Assets } \\
\text { - Commercial Liabilities } \\
\text { - Severance Payment } \\
\text { - Other Liabilities } \\
\text { = Gross Cash Investment }\end{array}$ & 4 & $\begin{array}{l}\text { Net Monetary Assets } \\
+ \text { Inventory } \\
+ \text { Underground and Overground Facilities } \\
=\text { Terminal Value }\end{array}$ \\
\hline
\end{tabular}

\footnotetext{
${ }^{2}$ Bayrakdaroğlu, A., Ege İ., (2009) Performance Analysis of Entities Listed in Istanbul Stock Exchange with Cash Flow Return on Investment (CFROI) Method, Muhan Soysal Business Conference, METU, February 10
} 
Economic lives of entity assets are calculated by dividing the depreciable gross tangible fixed assets (which is obtained by adding the accumulated depreciation amount to net tangible fixed assets) by annual depreciation expense. Gross cash flows are calculated by adding depreciation expense and interest expense for the period to net profit. Depreciable assets and intangible assets are added together and the result is added to underground and overground facilities figure, then this result is summed up with the net figure obtained by subtracting monetary liabilities (comprised of the total of commercial liabilities, severance payment and other liabilities) from monetary assets (comprised of the total of cash and cash equivalents, commercial and related receivables and other current assets).

\subsection{Cash Value Added (CVA)}

Cash Value Added (CVA), is a value based performance measure developed by Fredrik Weissenrieder-Anelda Consultancy Firm and it is based on cash flows. Boston Consulting Group (2000) suggested direct calculation of CVA as shown below.

CVA = Operating Cash Flows - Economic Depreciation - Gross Investments Cost of Capital (Gross Cash Investment $x$ Weighted Average Cost of Capital)

\subsection{Market Value Added (MVA)}

Considered as a continuation of EVA, MVA is a measure comparing the entity capital's market value with its book value. MVA is the difference between the entity capital's market value and the capital amount actually provided by shareholders. In other words, MVA is the difference between the capital investment originally made in the entity by investors and the value these investors would obtain if they sell this investment over the share prices applicable in the current/relevant period.

MVA is closely related with economic profitability. It measures whether the entity succeeded to add some premium on the total resources (debt + equity) it has. MVA shows whether the invested capital is efficiently used. It demonstrates a cumulative measure since it enables estimation of the retrospective entity performance.

MVA formula is given below.

MVA = Market Value - Equity Book Value $=($ Total \# of Shares $x$ Share Closing Price $)-($ Equity Book Value $)$

\section{FINDINGS}

\subsection{An Implementation According to Economic Value Added Model (EVA)}

The following table includes data from Company $X$ which are taken as basis to calculate the Economic Value Added (EVA).

\begin{tabular}{|c|c|c|c|c|c|c|}
\hline Fund Type & Amount (A) & $\begin{array}{c}\text { Weight } \\
\text { within Fund } \\
\text { (B) }\end{array}$ & $\begin{array}{c}\text { Interest } \\
\text { Rate (C) }\end{array}$ & $\begin{array}{c}\text { Tax Rate } \\
\text { (D) }\end{array}$ & $\begin{array}{c}\text { (E) Cost after } \\
\text { Tax (C-(C*D)) }\end{array}$ & $\begin{array}{c}\text { (F) Weighted } \\
\text { Average Cost } \\
\text { (E*B) }\end{array}$ \\
\hline Note & $9,000,000$ & $60 \%$ & $30 \%$ & $20 \%$ & $24 \%$ & $14.40 \%$ \\
\hline Bond & $4,500,000$ & $30 \%$ & $35 \%$ & $20 \%$ & $28 \%$ & $8.40 \%$ \\
\hline Stock & $1,500,000$ & $10 \%$ & $40 \%$ & $20 \%$ & $32 \%$ & $3.20 \%$ \\
\hline Total & $\mathbf{1 5 , 0 0 0 , 0 0 0}$ & & & & & $\mathbf{2 6 \%}$ \\
\hline
\end{tabular}

Weighted Average Cost of Capital $=15,000,000 * 0.26=3,900,000$ TRY

Assuming the after tax profit of entity is 5,000,000 TRY;

$\mathrm{EVA}=5,000,000-3,900,000=1,100,000 \mathrm{TRY}$

In this example, shareholders gain would be 3,900,000 TRY in case they invest in an alternative investment, however they gained an additional $1,100,000$ TRY by preferring to invest in Company X. The said amount is the Economic Value Added (EVA). 


\subsection{An Implementation for Energy Firms According to Cash Flow Return on Investment Model (CFROI)}

The investments of energy firms have a quite significant share in their balance sheets, therefore we chose to use 2014 and 2015 data published on Public Disclosure Platform (KAP) from the eligible energy firms listed in Istanbul Stock Exchange Market for the implementation part of this study. Balance sheet data used in the implementation is 12-month data audited by independent auditors and are obtained from official KAP website. Balance sheet data are used for capital structure (debt - equity share) during calculation of Weighted Average Cost of Capital. However, interest rate is taken as $15 \%$ as a common measure since it is quite difficult to determine the cost of borrowing for each firm.

After determining the firms' costs of borrowing and costs of equity, weighted Average Cost of Capital is found by adding up the multiplication results of the said costs by their balance sheet weight. Following table contains data used in CFROI calculation for the analysis of energy industry firms.

Table 3: Calculation of Economic Life (Years) for 2014

\begin{tabular}{|l|r|r|r|r|r|}
\hline Firms & $\begin{array}{r}\text { Net Tangible } \\
\text { Fixed Assets (A) }\end{array}$ & $\begin{array}{r}\text { Accumulated } \\
\text { Depreciation } \\
\text { (B) }\end{array}$ & $\begin{array}{r}\text { Depreciable Gross } \\
\text { Tangible Fixed Assets } \\
\text { (A+B)=C }\end{array}$ & $\begin{array}{r}\text { Annual } \\
\text { Depreciation (D) }\end{array}$ & $\begin{array}{r}\text { Economic Life } \\
\text { (Years) (D/C) }\end{array}$ \\
\hline Ak & $2,498,864,172$ & $350,205,947$ & $2,849,070,119$ & $86,185,571$ & 33.06 \\
\hline Aksa & $2,684,611,121$ & $680,936,495$ & $3,365,547,616$ & $121,139,342$ & 27.78 \\
\hline Aksu & $6,763,268$ & 697,627 & $7,460,895$ & 420,790 & 17.73 \\
\hline Ayen & $912,416,269$ & $108,139,678$ & $1,020,555,947$ & $28,217,184$ & 36.17 \\
\hline Orge & 331,334 & 390,666 & 722,000 & 115,092 & 6.27 \\
\hline Zorlu & $3,160,281$ & 793,109 & $3,953,390$ & 138,370 & 28.57 \\
\hline
\end{tabular}

Table 4: Calculation of Economic Life (Years) for 2015

\begin{tabular}{|l|r|r|r|r|r|}
\hline Firms & $\begin{array}{r}\text { Net Tangible } \\
\text { Fixed Assets (A) }\end{array}$ & $\begin{array}{r}\text { Accumulated } \\
\text { Depreciation } \\
\text { (B) }\end{array}$ & $\begin{array}{r}\text { Depreciable Gross } \\
\text { Tangible Fixed Assets } \\
\text { (A+B)=C }\end{array}$ & $\begin{array}{r}\text { Annual } \\
\text { Depreciation (D) }\end{array}$ & $\begin{array}{r}\text { Economic Life } \\
\text { (Years) (D/C) }\end{array}$ \\
\hline Ak & $4,049,357,799$ & $37,748,375$ & $4,087,106,174$ & $155,223,307$ & 26.33 \\
\hline Aksa & $3,031,979,261$ & $823,486,248$ & $3,855,465,509$ & $144,820,588$ & 26.62 \\
\hline Aksu & $17,697,098$ & $1,044,550$ & $18,741,648$ & 376,171 & 49.82 \\
\hline Ayen & $1,153,032,787$ & $140,930,582$ & $1,293,963,369$ & $32,489,249$ & 39.83 \\
\hline Orge & 475,074 & 346,793 & 821,867 & 126,017 & 6.52 \\
\hline Zorlu & $4,022,422$ & 940,726 & $4,963,148$ & 143,394 & 34.61 \\
\hline
\end{tabular}

Reviewing Table 3-4; first the depreciable gross tangible fixed asset figure is found for the energy firms by adding up their net tangible fixed asset and accumulated depreciation figures; then the annual depreciation amount is divided by this figure, and the result gives the economic lives of the depreciable assets. According to this data, we can see that economic lives of the firms' depreciable assets is minimum 6 and maximum 36 years for 2014 and minimum 6 and maximum 50 years for 2015 . 
Table 5: Calculation of Economic Depreciation for 2014

\begin{tabular}{|c|c|c|c|c|c|c|c|c|c|c|}
\hline Firms & Fund Type & $\begin{array}{l}\text { Amount } \\
\text { (A) }\end{array}$ & $\begin{array}{l}\text { Weight } \\
\text { within } \\
\text { Fund (B) }\end{array}$ & $\begin{array}{l}\text { Interest } \\
\text { Rate (C) }\end{array}$ & $\begin{array}{l}\text { Tax } \\
\text { Rate } \\
\text { (D) }\end{array}$ & $\begin{array}{l}\text { (E) Cost } \\
\text { after } \\
\text { Tax (C- } \\
\text { (C*D)) }\end{array}$ & $\begin{array}{c}\text { (F) } \\
\text { Weighted } \\
\text { Average } \\
\text { Cost (E*B) }\end{array}$ & $\begin{array}{l}\text { Weighted } \\
\text { Average } \\
\text { Cost of } \\
\text { Capital }\end{array}$ & $\begin{array}{c}\text { Tangible Fixed } \\
\text { Assets }\end{array}$ & $\begin{array}{c}\text { Economic } \\
\text { Depreciation }\end{array}$ \\
\hline Ak & $\begin{array}{l}\text { Long Term } \\
\text { Securities }\end{array}$ & 100,000 & $100 \%$ & $7.78 \%$ & $20 \%$ & $6.22 \%$ & $6.22 \%$ & 6,224 & $2,498,864,172$ & $5,743,668$ \\
\hline Aksa & - & 0 & 0 & $13 \%$ & $20 \%$ & $10.40 \%$ & 0 & 0 & $268,461,112$ & 0 \\
\hline Aksu & - & 0 & 0 & $9.02 \%$ & $20 \%$ & $7.22 \%$ & 0 & 0 & $6,763,268$ & 0 \\
\hline Ayen & $\begin{array}{l}\text { Financial } \\
\text { Assets }\end{array}$ & 464,936 & $100 \%$ & $12.27 \%$ & $20 \%$ & $9.82 \%$ & $9.82 \%$ & 45,638 & $912,416,269$ & $1,041,232$ \\
\hline Örge & - & 0 & 0 & $5.98 \%$ & $20 \%$ & $4.78 \%$ & 0 & 0 & 331,334 & 0 \\
\hline Zorlu & $\begin{array}{l}\text { Long Term } \\
\text { Securities }\end{array}$ & 246 & $100 \%$ & $7.50 \%$ & $20 \%$ & $6 \%$ & 0 & 15 & $3,160,281$ & 0 \\
\hline
\end{tabular}

Table 6: Calculation of Economic Depreciation for 2015

\begin{tabular}{|l|c|c|c|c|c|c|c|c|c|c|}
\hline Firms & Fund Type & $\begin{array}{c}\text { Amount } \\
\text { (A) }\end{array}$ & $\begin{array}{c}\text { Weight } \\
\text { within } \\
\text { Fund } \\
\text { (B) }\end{array}$ & $\begin{array}{c}\text { Interest } \\
\text { Rate (C) }\end{array}$ & $\begin{array}{c}\text { Tax } \\
\text { Rate } \\
\text { (D) }\end{array}$ & $\begin{array}{c}\text { (E) Cost } \\
\text { after } \\
\text { Tax (C- } \\
\text { (C*D)) }\end{array}$ & $\begin{array}{c}\text { (F) } \\
\text { Weighted } \\
\text { Average } \\
\text { Cost (E*B) }\end{array}$ & $\begin{array}{c}\text { Weighted } \\
\text { Average } \\
\text { Cost of } \\
\text { Capital }\end{array}$ & $\begin{array}{c}\text { Tangible Fixed } \\
\text { Assets }\end{array}$ \\
\hline Ak & $\begin{array}{c}\text { Long Term } \\
\text { Securities }\end{array}$ & 100,000 & $100 \%$ & $11.01 \%$ & $20 \%$ & $8.81 \%$ & $8.81 \%$ & 8,808 & $4,049,357,799$ \\
Depreciation \\
\hline Aksa & - & 0 & 0 & $11.05 \%$ & $20 \%$ & $8.84 \%$ & 0 & 0 & $3,031,979,261$ & $1,227,322$ \\
\hline Aksu & - & 0 & 0 & $10.74 \%$ & $20 \%$ & $8.59 \%$ & 0 & 0 & $17,697,098$ & 0 \\
\hline Ayen & $\begin{array}{c}\text { Financial } \\
\text { Assets }\end{array}$ & 412,408 & $100 \%$ & $15 \%$ & $20 \%$ & $12 \%$ & $12 \%$ & 49,489 & $1,153,032,787$ \\
\hline Örge & - & 0 & 0 & $10.78 \%$ & $20 \%$ & $8.62 \%$ & 0 & & 0 & $4,405,368$ \\
\hline Zorlu & $\begin{array}{c}\text { Long Term } \\
\text { Securities }\end{array}$ & 246 & $100 \%$ & $8.88 \%$ & $20 \%$ & $7.10 \%$ & $7.10 \%$ & 17 & $4,022,422$ \\
\hline
\end{tabular}

Reviewing Table 5-6; tangible fixed assets, funds, weight of each fund within the overall fund portfolio, interest rate and tax rate data is obtained from the firm's financial statements and B/S footnotes for calculation of economic depreciation amounts of the energy firms; then the Weighted Average Cost of Capital (WACC) is calculated with the following formula.

$$
E A=\frac{\text { WACC }}{\left(1+W^{2} C C\right)^{N}-1} \times \text { Depreciable Assets }
$$

According to these data, economic depreciation amount for Ak Enerji and Ayen Enerji can be calculated, but the other firms have no funds so the calculation cannot be made; Ak Enerji's economic depreciation amount is higher than Ayen Enerji's in 2014, and the case is just the contrary for 2015. 
Table 7: Calculation of Gross Cash Flow for 2014

\begin{tabular}{|l|r|r|r|r|}
\hline Firms & Net Profit (A) & $\begin{array}{r}\text { Depreciation } \\
\text { Expense (B) }\end{array}$ & $\begin{array}{r}\text { Interest } \\
\text { Expense (C) }\end{array}$ & $\begin{array}{r}\text { Gross Cash Flow } \\
\text { (A+B+C) }\end{array}$ \\
\hline Ak & $-321,251,586$ & $86,185,571$ & $126,248,795$ & $-108,817,220$ \\
\hline Aksa & $39,437,144$ & $121,139,342$ & 646,892 & $161,223,378$ \\
\hline Aksu & $-1,118,380$ & 420,790 & 229 & $-697,361$ \\
\hline Ayen & $29,953,521$ & $28,217,184$ & $36,252,079$ & $94,422,784$ \\
\hline Orge & $3,543,181$ & 115,092 & 906,299 & $4,564,572$ \\
\hline Zorlu & $-224,448$ & 138,370 & 421,595 & 335,517 \\
\hline
\end{tabular}

Table 8: Calculation of Gross Cash Flow for 2015

\begin{tabular}{|l|r|r|r|r|}
\hline Firms & Net Profit (A) & $\begin{array}{r}\text { Depreciation } \\
\text { Expense (B) }\end{array}$ & $\begin{array}{r}\text { Interest } \\
\text { Expense (C) }\end{array}$ & $\begin{array}{r}\text { Gross Cash Flow } \\
\text { (A+B+C) }\end{array}$ \\
\hline Ak & $-351,005,560$ & $155,223,307$ & $220,722,801$ & $29,940,548$ \\
\hline Aksa & $-228,419,769$ & $144,820,588$ & $44,262,305$ & $39,336,876$ \\
\hline Aksu & $1,382,143$ & 376,171 & 62,942 & $1,821,256$ \\
\hline Ayen & $-29,522,057$ & $32,489,249$ & $43,958,978$ & $46,926,170$ \\
\hline Orge & $10,433,485$ & 126,017 & 475,087 & $11,034,589$ \\
\hline Zorlu & $-267,755$ & 143,394 & 449,679 & 325,318 \\
\hline
\end{tabular}

In Table 7-8, gross cash flow figures are obtained by adding the firms' net profit amounts for the current period with depreciation and interest expenses. The results of the calculation show that the highest gross cash flow figure for year 2014 belongs to Aksa and the lowest belongs to Ak Enerji; for 2015 the highest figure belongs to Ayen and the lowest to Zorlu Enerji.

Table 9: Calculation of Gross Cash Investment for 2014

\begin{tabular}{|c|c|c|c|c|c|c|c|c|c|}
\hline Firms & $\begin{array}{r}\text { Depreciable } \\
\text { Assets }\end{array}$ & $\begin{array}{r}+ \text { Intangible } \\
\text { Assets }\end{array}$ & $\begin{array}{r}\text { + Cash and } \\
\text { Cash } \\
\text { Equivalents }\end{array}$ & $\begin{array}{r}+ \text { Commercial } \\
\text { and Related } \\
\text { Receivables }\end{array}$ & $\begin{array}{c}\text { + Other } \\
\text { Current } \\
\text { Assets }\end{array}$ & $\begin{array}{r}\text { - Commercial } \\
\text { Liabilities }\end{array}$ & $\begin{array}{r}\text { - Severance } \\
\text { Payment }\end{array}$ & $\begin{array}{r}\text { - Other } \\
\text { Liabilities }\end{array}$ & $\begin{array}{l}\text { Gross Cash } \\
\text { Investment }\end{array}$ \\
\hline Ak & $2,498,864,172$ & $118,567,643$ & $82,229,586$ & $125,329,514$ & $1,042,354$ & $77,093,589$ & $1,565,946$ & $3,656,511$ & $2,743,717,223$ \\
\hline Aksa & $2,684,611,121$ & $9,513,949$ & $34,238,000$ & $88,689,954$ & $9,213,837$ & $265,401,145$ & $1,829,338$ & $14,336,828$ & $2,544,699,550$ \\
\hline Aksu & $6,763,268$ & $10,072,706$ & $3,311,870$ & 290,841 & 0 & 13,402 & 41,293 & 421 & $20,383,569$ \\
\hline Ayen & $912,416,269$ & $41,506,289$ & $188,692,607$ & $31,100,923$ & 218,160 & $79,316,772$ & $2,054,245$ & $59,521,797$ & $1,033,041,434$ \\
\hline Orge & 331,334 & 1,792 & $1,141,123$ & $27,502,178$ & 242,845 & $1,912,315$ & 327,960 & 383,519 & $26,595,478$ \\
\hline Zorlu & $3,160,281$ & 15,516 & 108,178 & 98,262 & 2,416 & 115,394 & 541 & 70,620 & $3,198,098$ \\
\hline
\end{tabular}


Table 10: Calculation of Gross Cash Investment for 2015

\begin{tabular}{|c|c|c|c|c|c|c|c|c|c|}
\hline Firms & $\begin{array}{r}\text { Depreciable } \\
\text { Assets }\end{array}$ & $\begin{array}{r}+ \text { Intangible } \\
\text { Assets }\end{array}$ & $\begin{array}{r}\text { + Cash and } \\
\text { Cash } \\
\text { Equivalents }\end{array}$ & $\begin{array}{r}+ \text { Commercial } \\
\text { and Related } \\
\text { Receivables }\end{array}$ & $\begin{array}{r}+ \text { Other } \\
\text { Current } \\
\text { Assets }\end{array}$ & $\begin{array}{r}\text { - Commercial } \\
\text { Liabilities }\end{array}$ & $\begin{array}{r}\text { - Severance } \\
\text { Payment }\end{array}$ & $\begin{array}{r}\text { - Other } \\
\text { Liabilities }\end{array}$ & $\begin{array}{l}\text { Gross Cash } \\
\text { Investment }\end{array}$ \\
\hline Ak & $4,049,357,799$ & $115,808,714$ & $476,767,228$ & $105,827,317$ & $2,253,044$ & $136,168,572$ & $1,492,719$ & $3,009,874$ & $4,609,342,937$ \\
\hline Aksa & $3,031,979,261$ & $10,280,998$ & $48,452,416$ & $182,621,158$ & $5,005,240$ & $400,144,104$ & $1,519,007$ & $13,056,474$ & $2,863,619,488$ \\
\hline Aksu & $17,697,098$ & $9,684,367$ & $2,084,458$ & 111,108 & 125,327 & 26,165 & 49,110 & 21,642 & $29,605,441$ \\
\hline Ayen & $1,153,032,787$ & $40,720,144$ & $152,593,651$ & $26,344,803$ & 69,657 & $68,343,642$ & $2,720,724$ & $138,276,173$ & $1,163,420,503$ \\
\hline Orge & 475,074 & 1,560 & $14,565,104$ & $34,873,191$ & 377,517 & $8,503,600$ & 449,679 & $1,971,749$ & $39,367,418$ \\
\hline Zorlu & $4,022,422$ & 18,787 & 153,670 & 71,271 & 2,080 & 254,232 & 733 & 177,814 & $3,835,451$ \\
\hline
\end{tabular}

In Table 9-10, intangible assets, cash and cash equivalents, commercial and related receivables and other current assets are added to depreciable assets to reach the firms' gross cash investment figures. Severance payment and other liabilities are deducted from the result of the foregoing calculation, thus gross cash investment figures are found. This calculation shows that the highest gross cash investment figure for 2014 belongs to Ak Enerji and the lowest to Zorlu Enerji; and for 2015 the highest figure belongs to Ak Enerji and the lowest to Zorlu Enerji again.

Table 11: Calculation of Firms' CFROI for 2014 (TRY)

\begin{tabular}{|l|r|r|r|r|r|}
\hline Firms & $\begin{array}{r}\text { Economic } \\
\text { Life } \\
\text { (years) }\end{array}$ & $\begin{array}{r}\text { Economic } \\
\text { Depreciation } \\
\text { (A) }\end{array}$ & $\begin{array}{r}\text { Gross Cash Flow } \\
\text { (B) }\end{array}$ & $\begin{array}{r}\text { Gross Cash } \\
\text { Investment ( C) }\end{array}$ & $\begin{array}{r}\text { CFROI } \\
\text { ((B-A)/C) }\end{array}$ \\
\hline Ak & 33 & $5,743,668$ & $-108,817,220$ & $2,743,717,223$ & -0.0418 \\
\hline Aksa & 27 & 0 & $161,223,378$ & $2,544,699,550$ & 0.0634 \\
\hline Aksu & 17 & 0 & $-697,361$ & $20,383,569$ & -0.0342 \\
\hline Ayen & 36 & $1,041,232$ & $94,422,784$ & $1,033,041,434$ & 0.0904 \\
\hline Orge & 6 & 0 & $4,564,572$ & $26,595,478$ & 0.1716 \\
\hline Zorlu & 28 & 0 & 335,517 & $3,198,098$ & 0.1049 \\
\hline
\end{tabular}

Table 12: Calculation of Firms' CFROI for 2015 (TRY)

\begin{tabular}{|l|r|r|r|r|r|}
\hline Firms & $\begin{array}{r}\text { Economic } \\
\text { Life } \\
\text { (years) }\end{array}$ & $\begin{array}{r}\text { Economic } \\
\text { Depreciation } \\
\text { (A) }\end{array}$ & $\begin{array}{r}\text { Gross Cash Flow } \\
\text { (B) }\end{array}$ & $\begin{array}{r}\text { Gross Cash } \\
\text { Investment ( C) }\end{array}$ & $\begin{array}{r}\text { CFROI } \\
\text { ((B-A)/C) }\end{array}$ \\
\hline Ak & 26 & $1,227,322$ & $24,940,548$ & $4,609,342,937$ & 0.0051 \\
\hline Aksa & 27 & 0 & $-39,336,876$ & $2,863619,488$ & -0.0137 \\
\hline Aksu & 50 & 0 & $1,821,256$ & $29,605,441$ & 0.0615 \\
\hline Ayen & 40 & $1,405,368$ & $46,926,170$ & $1,163,420,503$ & 0.0391 \\
\hline Orge & 7 & 0 & $11,034,589$ & $39,367,418$ & 0.2803 \\
\hline Zorlu & 35 & 0 & 325.318 & $3,835,451$ & 0.0848 \\
\hline
\end{tabular}


In Table 11-12, the firms' CFROI figures are tried to be calculated by considering the economic lives, economic depreciation amounts of tangible assets, gross cash flows and gross cash investment figures of firms obtained from the calculations in the previous tables and the following formula is used for CFROI calculation.

$\mathrm{CFROI}=(($ Gross Cash Flow - Economic Depreciation $) /$ Gross Cash Investment

According to this calculation, the highest CFROI figure for 2014 belongs to Orge and the lowest to Ak Enerji; for 2015 the highest belongs to Orge and the lowest to Aksa.

Table 13: Comparison of Gross Cash Flows with Total Cash Flows, Volume of Assets and Annual Turnovers for 2014

\begin{tabular}{|c|c|c|c|c|c|c|c|}
\hline Firms & $\begin{array}{r}\text { Gross Cash } \\
\text { Flow }\end{array}$ & Total Cash Flow & $\begin{array}{r}\text { Total Cash } \\
\text { Flow : Gross } \\
\text { Cash Flow } \\
\text { Ratio }\end{array}$ & Volume of Assets & $\begin{array}{r}\text { Volume of } \\
\text { Assets : Gross } \\
\text { Cash Flow Ratio }\end{array}$ & Annual Turnover & $\begin{array}{l}\text { Annual } \\
\text { Turnover: } \\
\text { Gross Cash } \\
\text { Flow Ratio }\end{array}$ \\
\hline Ak & $-108,817,220$ & $23,164,977$ & -0.21 & $3,244,110,714$ & -29.81 & $1,124,671,014$ & -10.34 \\
\hline Aksa & $161,223,378$ & $34,101,472$ & 0.21 & $3,459,740,786$ & 21.46 & $1,957,437,904$ & 12.14 \\
\hline Aksu & -697.361 & $3,311,870$ & -4.75 & $42,095,116$ & -60.36 & $1,546,446$ & -2.22 \\
\hline Ayen & $94,422,784$ & $188,692,607$ & 2 & $1,430,982,987$ & 15.16 & $229,960,881$ & 2.44 \\
\hline Orge & $4,564,572$ & 37.524 & 0.01 & $38,995,770$ & 8.54 & $24,785,245$ & 5.43 \\
\hline Zorlu & 335.517 & 82.241 & 0.25 & $4,959,329$ & 14.78 & 806.947 & 2.41 \\
\hline
\end{tabular}

Table 14: Comparison of Gross Cash Flows with Total Cash Flows, Volume of Assets and Annual Turnovers for 2015

\begin{tabular}{|c|c|c|c|c|c|c|c|}
\hline Firms & $\begin{array}{r}\text { Gross Cash } \\
\text { Flow }\end{array}$ & Total Cash Flow & $\begin{array}{r}\text { Total Cash } \\
\text { Flow : Gross } \\
\text { Cash Flow } \\
\text { Ratio }\end{array}$ & Volume of Assets & $\begin{array}{r}\text { Volume of Assets: } \\
\text { Gross Cash Flow } \\
\text { Ratio }\end{array}$ & Annual Turnover & $\begin{array}{r}\text { Annual } \\
\text { Turnover: } \\
\text { Gross Cash } \\
\text { Flow Ratio }\end{array}$ \\
\hline Ak & $24,940,548$ & $463,748,375$ & 18.59 & $5,330,857,302$ & 213.74 & $1,802,888,608$ & 72.29 \\
\hline Aksa & $-39,336,876$ & $48,286,238$ & -1.23 & $4,060,705,589$ & -103.23 & $2,319,960,775$ & -58.98 \\
\hline Aksu & $1,821,256$ & $2,084,458$ & 1.14 & $53,254,494$ & 29.24 & $3,252,561$ & 1.79 \\
\hline Ayen & $46,926,170$ & $152,593,651$ & 3.25 & $1,698,238,058$ & 36.19 & $283,822,999$ & 6.05 \\
\hline Orge & $11,034,589$ & $14,268,459$ & 1.29 & $61,310,553$ & 5.56 & $49,816,340$ & 4.51 \\
\hline Zorlu & 325,318 & 151,654 & 0.47 & $5,617,555$ & 17.27 & 575.036 & 1.77 \\
\hline
\end{tabular}

In Table 13-14, the firms' gross cash flow amounts are compared with total cash flow amounts, volume of assets and annual turnover figures. According to this comparison, the highest result belongs to Ak Enerji and the lowest to Aksa Enerji. But these results should be evaluated by considering the company sizes also.

Table 15: Comparison of CFROI and WACC Figures for 2014 (\%)

\begin{tabular}{|l|c|c|}
\hline Firms & CFROI & WACC \\
\hline Ak & -0.0418 & 0.0622 \\
\hline Aksa & 0.0634 & 0 \\
\hline Aksu & -0.0342 & 0 \\
\hline Ayen & 0.0904 & 0.0982 \\
\hline Orge & 0.1716 & 0 \\
\hline Zorlu & 0.1049 & 0.06 \\
\hline Average & $\mathbf{0 . 0 5 9 1}$ & $\mathbf{0 . 0 3 6 7}$ \\
\hline
\end{tabular}


Table 16: Comparison of CFROI and WACC Figures for 2015 (\%)

\begin{tabular}{|l|c|c|}
\hline Firms & CFROI & WACC \\
\hline Ak & 0.0051 & 0.0881 \\
\hline Aksa & -0.0137 & 0 \\
\hline Aksu & 0.0615 & 0 \\
\hline Ayen & 0.0391 & 0.12 \\
\hline Orge & 0.2803 & 0 \\
\hline Zorlu & 0.0848 & 0,071 \\
\hline Average & $\mathbf{0 . 0 7 6 2}$ & $\mathbf{0 . 0 4 6 5}$ \\
\hline
\end{tabular}

In Table 15-16, CFROI and WACC figures of firms operating in energy industry are compared. The results show that for year 2014, Aksa, Orge and Zorlu showed positive performance according to the value based performance measure CFROI since the CFROI figures of these firms are higher than their WACC figures. Ak, Aksu and Ayen have CFROI figures lower than their WACC figures, creating no value addition for their shareholders. As can be understood from these data, some of the firms within the industry succeed to create value addition for their shareholders whereas some cannot; average of the industry firms show an average CFROI figure of 0.0591 and WACC 0.0367 ; with these data we see that the industry can provide value addition to the shareholders in general.

For year 2015, Aksa, Orge and Zorlu showed positive performance according to the value based performance measure CFROI since the CFROI figures of these firms are higher than their WACC figures. Ak, Aksa and Ayen have CFROI figures lower than their WACC figures, creating no value addition for their shareholders. As can be understood from these data, some of the firms within the industry succeed to create value addition for their shareholders whereas some cannot; average of the industry firms show an average CFROI figure of 0.0762 and WACC 0.0465; with these data we see that the industry can provide value addition to the shareholders in general.

The calculations made show that the gross cash investments of energy firms are quite higher than their gross cash flows. Cash flows of the firms operating in this industry should be increased to be able to make a positive assessment in terms of company performance.

\section{CONCLUSION}

Performance measurement in business entities is an important factor for shareholders, managers, investors, creditors and other stakeholders for making decision. Today, conventional performance measures are replaced by contemporary ones. Business entities should appropriately and effectively use the performance measurement methods considering the increased challenge within the growing and globalized competition environment.

Depreciation amounts allocated to the fixed assets included in entity financial statements have significant impact on the entity's performance measurement results. The reason is, selection of depreciation method and the depreciation amount calculated according to this selected method can have positive or negative effects on the entity financial statements and performance measurement results. In this paper, we applied the value based performance measurement methods Economic Value Added (EVA) and Cash Flow Return on Investment (CFROI) to firms operating in the energy industry to analyze whether these firms could create any value added.

Financial data of various energy firms for years 2014 \& 2015are obtained from Public Disclosure Platform (KAP) and these data are analyzed according to the contemporary performance measurement model Cash Flow Return on Investment (CFROI). CFROI and WACC values of these firms are compared. When the industry firms 
are analyzed individually, some are seen to be able to create value added for their shareholders while same are not; on the other hand, the industry average shows that the industry can create value added for their shareholders in general.

In conclusion, specifying different depreciation periods and using different depreciation methods by entities can significantly impact their financial statements and creates difficulty in comparing the entities with each other. Changing the selected depreciation method also causes different results for the entities' EVA (Economic Value Added) and CFROI (Cash Flow Return on Investment) performance measures. Our implementation also shows that the differences in depreciation management of the energy industry firms have significant impact on the change in their performance indicators.

\section{REFERENCES}

Akbaş, H.E., Ekonomik Katma Değer Yaklaşımı ve Hissedar Değeri. Mali Çözüm Dergisi, 107:119-120.

Bastı, E., Yılmaz T., IMKB'de İşlem Gören Yerli ve Yabancı İmalat Sanayi Şirketlerinin Ekonomik Katma Değer (EVA) ve Piyasa Katma Değerine (MVA) Dayalı Performans Analizi, Finans Politik \&Ekonomik Yorumlar,50(578):62.

Bayrakdaroğlu, A., Ege ì., (2009)

Yatırımın Nakit Akım Karlılığı (CFROI) Yöntemi ile IMKB'de İşlem Gören İşletmelerin Performanslarının Analizi.

Muhan Sosyal işletmecilik Konferansı, ODTÜ, 10 Şubat.

Clinton, B.D. and S.Chen,(1998) “Do New Performance Measures Measure Up? Management Accounting, 80 (4): 38-43.

Çakıcı, C., (2008), Ekonomik Katma Değer (EVA) Yaklaşımı, Beta Basım, İstanbul,181.

Epstein, Barry Mirza, Abbas Ali (2002) “Interpretation Application of International Accounting Standards” John Wiley \& Sons, Inc., USA $, 292,294$

Erasmus, P.,(2008), "The Relative and Incremental Information of the Value Based Financial Performance Meause Cash Value Added (CVA)", Journal of the Southern African Institute for Management Scientests, 17 (1):2-15

Fernandez, P. (2002), "Three Residual Income Valuation Methods and Discounted Cash Flow Valuation", Working Paper No:453, January. Erişim Adresi: http://ssrn.com/abstract=296945.

Günther, T., B. Landrock and T. Muche, (2000), "Profit versus Value Based Performance Measures. An Empirical Investigation Based on the Correlation with Capital Market for German DAX-100 Companies", Controlling, 1(2): 69-75 and 2(3): 129-134.

Hejazi, R. and M.M. Oskouei (2007), "The Information Content of Cash Value Added (CVA) and P/E Ratio: Evidence on Association with Stock Returns for Industrial Companies in the Tehran Stock Exchange", Iranian Accounting and Auditing Review, 14(47): 21-36.

Jacobs, J.F. (2007), "Neither EVA ${ }^{\circledR}$ nor CVA ${ }^{\circledR}$, but NVA Measuring Financial Performance, Uninterrupted, from Start to Finish, Social Science Research Network Electronic Paper Collection, Erişim Adresi: http://ssrn.com/abstract=366561.

Kara, H., (2005), Katma Değer Yaratmaya Dayalı Finansal Performans Ölçütü Olarak EVA(Economic Value Added) iMKB Şirketleri Üzerine Bir Uygulama, SPK Yayınları, Ankara, 234.

Kieso, D.E. \& Weygant, J.J. (1992) Intermediate Accounting, Seventh Edition, John Wiley and Sons. Inc.,s.547

Larson, K.D. \& Miller, P.B.W, (1993). Fundamental Accounting Principles, Irwin Inc., Boston,542.

Li, Y. X. and X.Y. Guo, (2003), "Selection of Performance Measurement Methods in Corporations: CVA or EVA?", Journal of Dalian University of Technology (Social Sciences), 3: 12-27.

Pratt, J. (1993). Financial Accounting, Second Edition, South-Western Publishing Co., Cincinnati Ohio, (158), s.17-20

Stewart, G,B., (1991), The EVA Management Guide: The Quest for Vlue, Harper Business Publishers,174.

Tuğay, O., Maddi Duran Varlıklarda Amortisman Uygulamalarının TMS 16 ve Vergi Mevzuatı Açısından İncelenmesi. Çukurova Üniversitesi iiBF Dergisi, 17(2):172.

Urbanczyk, E., E.M. Jaroszewicz and A.S. Urbaniak, (2005), "Economic Value Added Versus Cash Value Added: The Case Of Companies In Transitional Economy, Poland", International Journal of Banking and Finance, 3(1): 107-117.

Ünlü, U., Yatırımın Nakit Akım Karlılığı (CFROI) ve Nakit Katma Değer (CVA) Yöntemi Borsa İstanbul'da İşlem Gören Çimento Firmaları Üzerine Ampirik Bir Uygulama. Eskişehir Osmangazi Üniversitesi IïBF Dergisi,9(2),169-182. 
Yüreğir O.H., Nakıboğlu G., Performans Ölçümü ve Ölçüm Sistemleri: Genel Bir Bakış.ç.Ü.Sosyal Bilimler Enstitüsü Dergisi,16(2),553.

www.kap.gov.tr, Erişim Tarihi:19.09.2016.

http://www.kgk.gov.tr/contents/files/TFRS 2015/TFRS/TFRS 5.pdf, Erişim Tarihi:04.03.2015.

http://www.kgk.gov.tr/contents/files/TFRS 2015/TMS/TMS16.pdf , Erişim Tarihi:04.03.2015.

http://www.kgk.gov.tr/contents/files/TFRS 2015/TMS/TMS38.pdf , Erişim Tarihi:04.03.2015.

http://www.kgk.gov.tr/contents/files/TFRS_2015/TMS/TMS40.pdf, Erişim Tarihi:04.03.2015. 